\title{
ASBABUN NUZUL SEBAGAI LANGKAH AWAL MENAFSIRKAN AL-QUR'AN
}

\author{
Wahyuddin*
}

\begin{abstract}
Abstrak
Alqur'an diturunkan oleh Allah untuk memberikan petunjuk kepada manusia kerah tujuan yang terang dan jalan yang lurus dengan menegakkan asas kehidupan yang didasarkan pada keimanan kepada Allah dan risalah-Nya. Al Qur'an juga memuat informasi-informasi peristiwa masa lalu, kejadian-kejadian sekarang serta beritaberita yang akan datang.

Para ahli tafsir sepakat bahwa sebagian besar kandungan Al-Qur'an diturunkanoleh Allah SWT untuk tujuan umum ini. Kehidupan Nabi SAW dan para sahabatnya telah menjadi saksi sejarah atas semua fenomena terkait dengan diturunkannya wahyu ilahi (Al Qur'an). Bahkan kajian mendalam terhadap sebab turunnya Al Qur'an pada generasi awal Islam akan terbuktibahwa terdapat peristiwa khusus yang memerlukan penjelasan hukum Allah SWT atau masih kabur bagi mereka.Kedudukan Muhammad SAW sebagai nabi mempunyai peran penting dalam menjelaskan semua peristiwa terkait diturunkannya Al Qur'an. Hal ini yang mendorong para sahabat senantiasa bertanya setiap menjumpai berbagai peristiw dalam kehidupan mereka. Oleh karena itu, peristiwa turunnya Al Qur'an selalu terkait dengan kehidupan para sahabat baik peristiwa yang bersifat khusus atau untuk pertanyaan yang muncul.Pengetahuan mengenai asbabun nuzul besar sekali manfaatnya bagi setiap orang yang hendak menafsirkan Al Qur'an. Pengetahuan tersebut dapat membuat seseorang mengetahui kandungan makna Al Qur'an secara tepat dan sekaligus dapat menghindarkan seseorang dari pemahaman yang salah.
\end{abstract}

Kata kunci : Asbabun Nuzul, langkah, penafsiran Al Qur'an

Pengertian Asbabun Nuzul :

“Semua yang disebabkan olehnya diturunkan suatu ayat atau beberapa ayat yang mengandung sebabnya, memberi jawaban terhadap suatu sebab atau menerangkan hukumnya pada saat terjadi peristiwa itu “

Berangkat dari pengertian di atas, sebab turunnya ayat-ayat al Qur'an dapat diklarifikasikan menjadi dua macam :

a. Didahului oleh "sebab"

Hal ini bisa terjadi bila terjadi suatu peristiwa, maka turunlah ayat Al Qur'an mengenai peristiwa itu. Sebab turunnya ayat itu adakalanya berupa peristiwa yang terjadi di masyarakat Islam atau adakalanya berupa pertanyaan dari kalangan

${ }^{*}$ Dosen pada UPM Soshum ITS

jsh Jurnal Sosial Humaniora, Vol 3 No.1, Juni 2010 
Islam atau dari kalangan lain yang diarahkan kepada Nabi (Az Zarqony, 1988: 106). Seperti yang diriwayatkan ibn Abbas berkaitan dengan sebab turunnya ayat 214 dalam surat Asy-Syura :

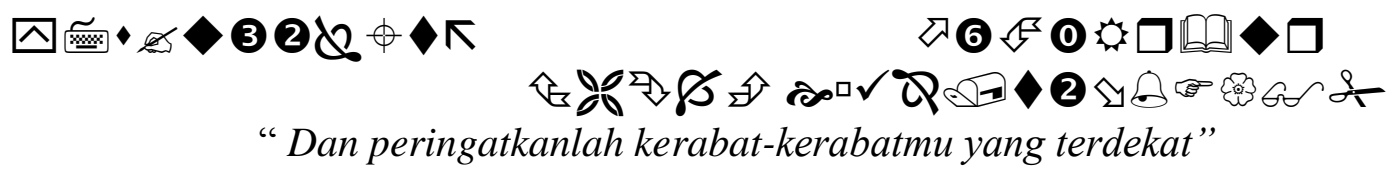

Langkah nabi SAW ketika turun ayat tersebut adalah mengumpulkan kerabat dekatnya dengan memberikan peringatan (Imam Bukhary, 1995 : 93). Nabi pergi dan naik ke bukit sofa, seraya berseru: “ Wahai kaumku !”. Maka mereka berkumpul di dekat nabi SAW. Beliau berkata : " Bagaimana pendapatmu bila aku beritahukan kepadamu bahwa dibalik gunung ini ada sepasukan kuda yang hendak menyerangmu.Percayakah kamu apa yang saya katakan. " Mereka menjawab: " Kami belum pernah melihat anda berbuat dusat " Nabi melanjutkan : Aku memperingatkan kamu tentang sikas yang pedih”. Ketika itu abu lahab berkata: “ Celakalah engkau, apakah engkau mengumpulkan kami hanya untuk urusan ini?”. Laluia berdiri, lalu turunlah al lahab:

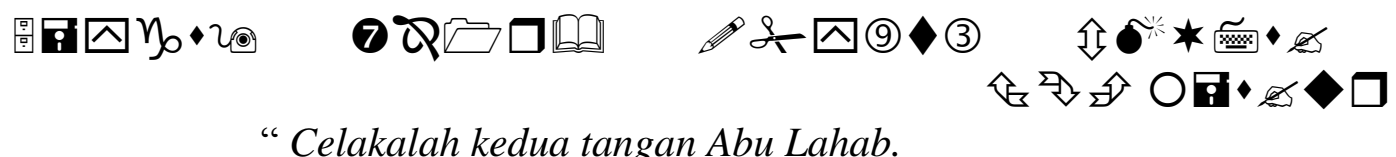

b. Bila Rasulullah ditanya tentang sesuatu hal, maka turunlah ayat al qur'an menerangkan hukumnya.

Peristiwa dhihar, adalah bila seorang laki-laki menyerupakan isterinya dengan ibunya sehingga isterinya itu haram atasnya, seperti kata suami kepada isterinya, “ Engkau tampak olehku seperti punggung ibuku.” Ucapan yang demikian yang tidak diteruskan kepada talaq, maka ia wajib membayar kifarat dan haram bercampur dengan istrinya sebelum membayar kafarat itu ( Ibn Rusd : 75) yang menimpa sahabat Khaulah bunti Sa'labah merupakan fakta yang mendukung pernyataan di atas. Musibah zihar yang dikenakan oleh suaminya. Aus bin Samit, mendapat perhatian serius dari Allah SWT. Sehingga malaikat Jibril turun membawa ayat dalam surat Al Mujadalah : 1 terkait dengan peristiwa tersebut. 


\section{पि

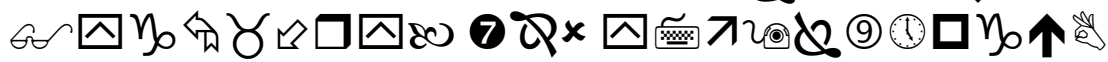 \\ "Sesungguhnya Allah telah mendengar perkataan perempuan yang mengadu kepadamu tentang suaminya ...."}

Ketika Aus bin Samit menjatuhkan Zihar kepada Istrinya Khaulah bin Sa'labah, lalu isterinya datang kepada Nabi SAW. Mengadukan hal itu. Aisyah r.a berkata: “ Maha suci Allah yang pendengaran-Nya meliputi segalanya. Aku mendengar ucapan Khaulah binti Sa'labah itu, sekalipun tidak seluruhnya. Ia mengadukan suaminya kepada Rasulullah SAW. Katanya: “ Rasulullah suamiku telah menghabiskan masa mudaku dan sudah berapa kali aku mengandung karenanya, sekarang setelah aku menjadi tua dan tidak beranak lagi ia menjatuhkan zihar kepadaku! Ya Allah sesungguhnya aku mengadu kepadaMu.Aisyah berkata "Tiba-tiba Jibril turun membawa ayat tersebut”.

Namun demikian, ternyata ada diantara ayat Al Qur'an yang diturunkan sebagai permulaan tanpa sebab. A'isyah Abdurahman pakar tafsir kontemporer, yang terkenal dengan julukan Bintuys-Syathi', mengusulkan penolakan untuk menganggap setiap peristiwa dalam Asbabun Nuzul tersebut sebagai sebab atau bahkan tujuan turunnya wahyu, tapi sekedar merupakan wahyu kondisi-kondisi eksternal dari pewahyuan itu, sehingga penekanannya diletakkan pada universalitas makna dan bukan pada kekhususan kondisi tersebut (A'isyah Abdurrahman, 1996: 15). Seperti yang berkaitan dengan akidah, kewajiban iman, kewajiban Islam dalam kehidupan pribadi dan sosial.

As-Syuyuti berpendapat bahwa ayat-ayat al qur'an tidak diturunkan di saat-saat terjadinya sebab. Ia berpendapat demikian karena hendak mengkritik atau membatalkan penafsiran surah Al fiil, bahwa sebab turunnya surah tersebut adalah kisah datangnya orang-orang Habasyah yang hendak menghancurkan ka'bah dibawah komando raja Abrahah, Jurzi Zaidan memberikan analisis terkait dengan maksud dan tujuan raja Abrahah untuk menguasai Mekkah karena lokasi kotanya berada di sepanjang rute perdagangan yang membentang dari Arabia selatan dan utara. Ia menjadi jalur lalu lntas peragangan terpenting mulai dari Mediteranian, Teluk Persia, laut merah sampai Afrika (Jurzi Zaidan, 1966 :350). Pada dasarnya kisah tersebut tidak sedikitpun berhubungan dengan sebab turunnya suarh al-fiil. 
Akan tetapi peristiwa dalam kandungan surah tersebut lebih mengarah pada informasi peristiwa masa lalu., seperti halnya kisah kaum nabi Nuh a.s., kaum Ad, kaum Samud dan lain-lain. Ayat-ayat itu mempunyai motif yang bersifat umum, yakni untuk menghibur Nabi SAW. Dan untuk menguatkan hatinya dalam menghadapi berbagai tantangan yang keras, terutama dari kaumnya sendiri.

\section{Faedah mengetahui Asbabun Nuzul}

Pengetahuan mengenai asbabun nuzul besr sekali manfaatnya bagi setiap orang yang hendak menafsirkan Al qur'an. Pengetahuan tentangnya dapat membantu seseorang mengetahu kiandungan makna al qur'an secara tepat dan sekaligus dapat menhindarkan dia dari salah satu pengertian. Diantara faedah itu adalah :

1. Mengetahui hikmah diundangkannya suatu hukum dan keperpihakan hukum syra' terhadap kpentingan umum.

2. Mengetahui pengukusan hukum yang diturunkan dengan sebab yang terjadi bila ternyata hukum itu dinyatakan dalam bentuk umum (Az Zarqony, 1988:110)

Contoh : Firman Allah SWT dalam surat Ali Imron ayat 188 yang berbunyi :

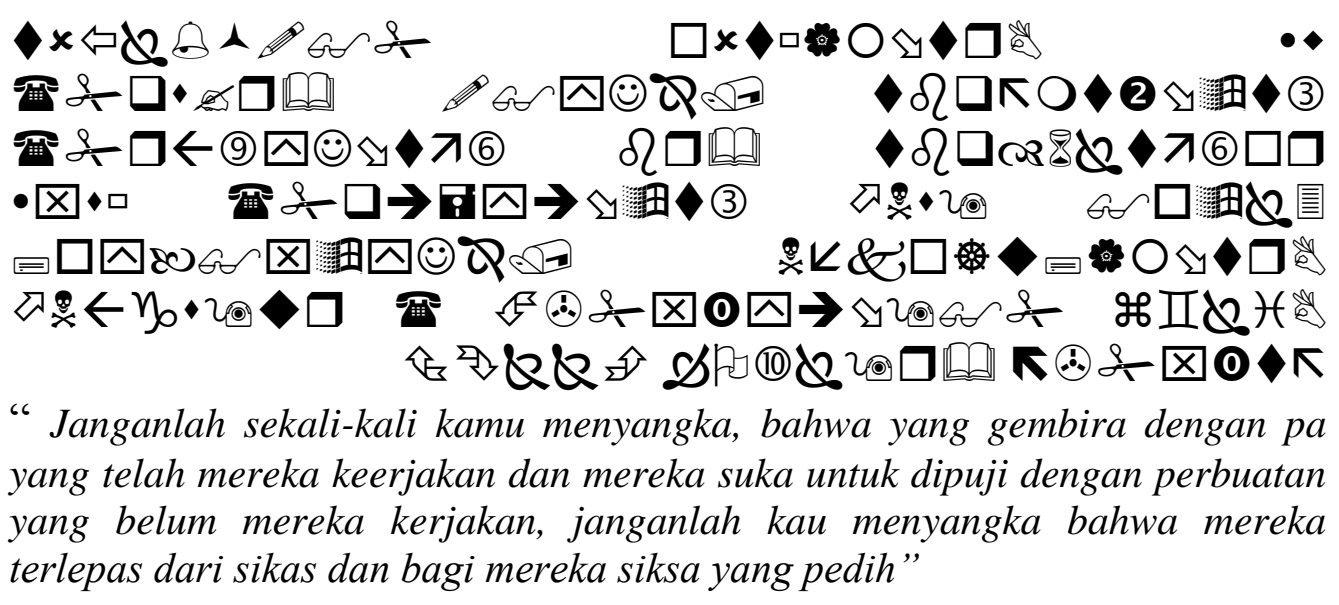

Asbabun nuzul ayat tersebut adalah peristiwa pada sahabat Marwan yang menanyakan kandungan ayat di atas kepada Ibn Abbas r.a. Marwan berkata: Sekiranya setiap orang diantara kita bergembira dengan apa yang telah dikerjakan dan ingin dipuji dengan perbuatan yang belum dikerjakan itu akan disiksa, 
tentulah kita semua akan disiksa. Dalam hal ini, Ibn Abbas r.a membantah pendapat Marwan dan menegaskan bahwa ayat tersebut diturunkan berkenan dengan Ahli kitab. Kemudian Ibn Abbas mengutip firman Allah SWT dalam surat Ali Imron : 187 yang berbunyi :

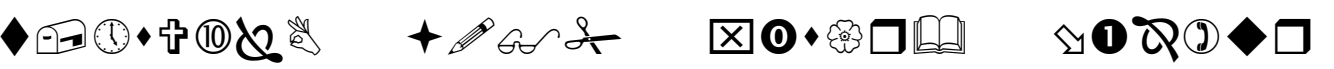

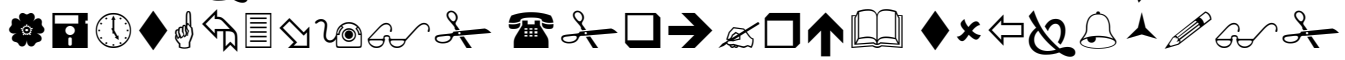

" Dan ingatlah ketika Allah mengambil janji dari orang-orang yang telah diberi kitab.”

Menurut Ibn Abbas r.a asbabun nuzul ayat tersebut adalah bahwa Rasul SAW. Menanyakan tentang sesuatu kepada Ahlu Kitab. Mereka sengaja menyembunyikannya, dan tidak memberikan jawaban malah mereka mengambil persoalan lain dan itu yang mereka tunjukkan kepada Rasul SAW (Lihat keterangan Jalaluddin As Syuyuty, 1996:93). Setelah itu mereka pergi dan menganggap bahwa mereka telah memberitahukan kepada Rasulullah apa yang ditanyakan kepada mereka. Dalam hal ini, ahlu kitab berkeinginan untuk dipuji oleh Rasul SAW. Mereka bergembira dengan apa yang telah mereka kerjakan yaitu menyembunyikan apa yang ditanyakan oleh Nabi kepada Ahlu Kitab.

3. Mengetahui lafad yang diturunkan bersifat umum dan terdapat dalil atas pengkhususannya contohnya firman Allah SWT. Dalam surat An Nur 23-24 sebagai berikut :

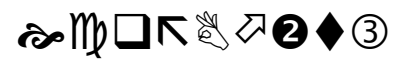

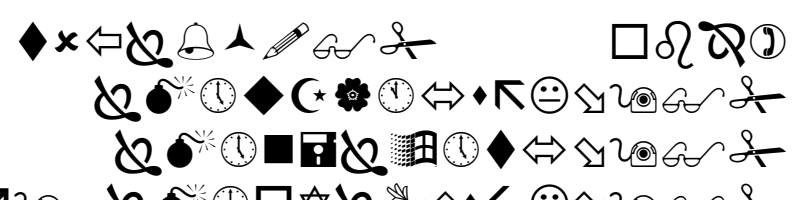

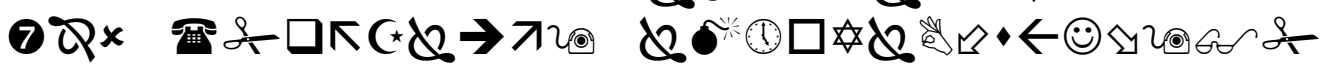

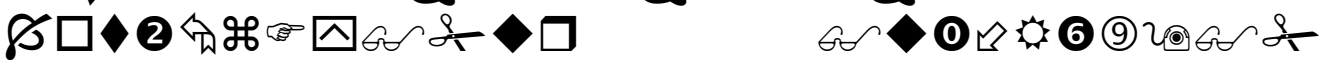

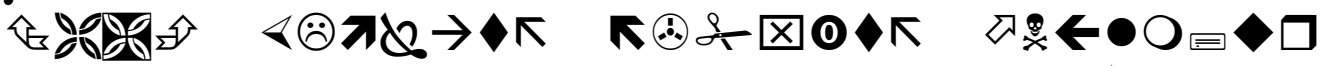

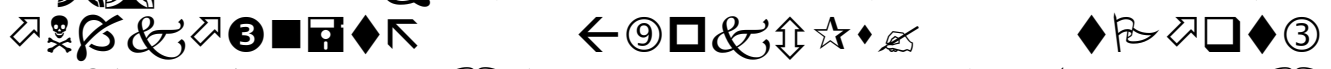

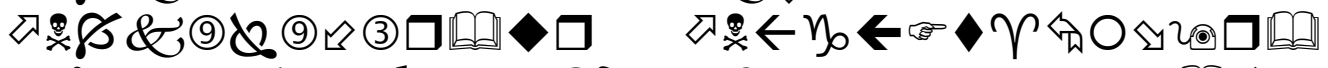
요아

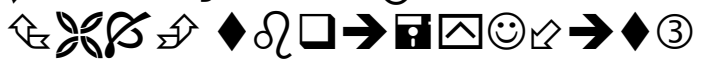

“ Sesungguhya orang yang menuduh (berzina)perempuan baik-baik yang tidak tahu menahu dan beriman, mereka kena laknat di dunia dan akhirat dan bagi mereka azab yang besar, pada hari (ketika) lidah, tangan dan kaki mereka menjadi saksi atas mereka mengenai apa yang telah mereka kerjakan dulu” 
Ayat ini turun dengan tuduhan berbuat zina pada pribadi Aisyah r.a secara khusus atau dengan Aisyah r.a dan istri-istri Nabi SAW lainnya. Menurut Ibn Abbas r.a ayat tersebut turun berkenaan dengan Aisyah r.a secara khusus dan istri-istri Nabi SAW. Allah tidak menerima taubat orang yang melakukan hal itu. dan menerima taubat orang yang menuduh seorang perempuan di antara perempuan-perempuan selain istri-istri Nabi SAW.

4. Mengetahui makna Al Qur'an dan menyikap kesamaran yang tersembunyi dalam ayat-ayat yang tidak dapat ditafsirkan tanpa mengetahui asbabun nuzul. Contohnya firman Allah dalam surat al baqarah 158 :

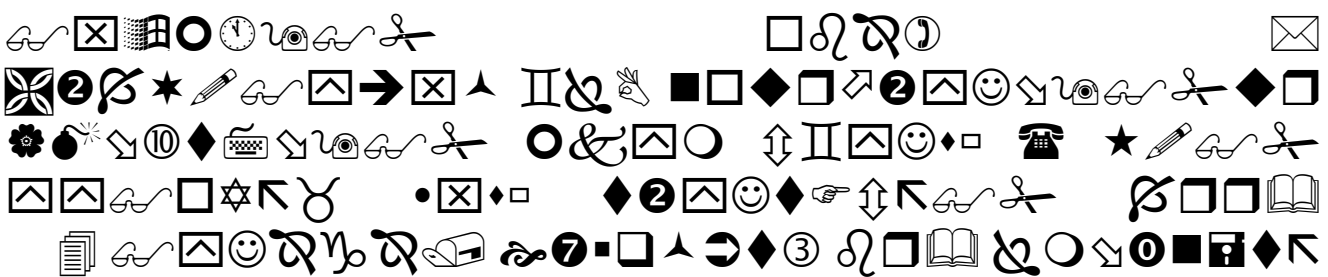

"Sesungguhnya Safa dan marwa adalah sebagian dari syia'ar Allah. Maka barang siapa beribadah haji ke Baitullah atau beumrah, maka tidaka ada dosa baginya untuk mengerjakan sa'i di antara keduanya....."

Secara tekstual ayat tersebut tidak menunjukkan bahwa sa'i itu wajib sebab tiada dosa untuk mengerjakannya itu menunjukkan membolehan dan bukannya kewajiban Aisyah r.a menjelaskan bahwa pada awalnya para sahabat merasa keberatan bersa'i antara Safa dan Marwa karena perbuatan tersebut berasal dari perbuatan jahiliyah. Begitu juga tradisi orang-orang Ansor sebelum masuk Islam biasa mendatangi 'Manat' (patung yang dipasang di antara Safa dan Marwa) untuk menyembahnya. Orang yang dulu menyembahnya tentu keberatan untuk bersa'i di antara Safa dan Marwa. Maka Allah SWT menurunkan ayat tersebut diatas. Selain itu, Nabi SAW telah menjelaskan sa'i diantara keduanya. Oleh karena itu. tidak seorangpun dapat meninggalkannya.

(Ali As Syayis, 1998 : 39-40) menyatakan bahwa para imam madzhab berbeda pendapat tentang hukum sa'i antara Shafa dan Marwa. Madzhab Syafi'i dan Ahmad berpendapat bahwa sa'i merupakan rukun haji. Pendapat tersebut berdasarkan hadist Nabi SAW yang diriwayatkan oleh Abdillah bin Muzamil yaitu: "Bersa'ilah! karena Allah telah mewajibkan sa'i” Abu 
Hanifah berpendapat bahwa sa'i bukan termasuk rukun haji dan sunah hukumnya. Hal ini berdasarkan hadist Nabi yang diriwayatkan oleh As-Sya'bi dari Urwah bin Mudhras at-Tai berkata: "Saya bertemu Rasulullah SAW di Muzdalifah." Saya bertanya: "Saya datang dari gunung Tai, tiada gunung yang saya lewati kecuali saya berhenti disitu. Maka apakah saya sudah berhaji?” Nabi Bersabda; "Barang siapa yang sholat bersama kita, berhenti bersama kita ditempat ini dan sebelumnya telah berada di Arofah maka dia sudah menunaikan haji dengan sempurna”

\section{Redaksi Asbabun Nuzul}

Penggunaan redaksi dalam menerangkan Asbabun Nuzul tidak selalu berupa pernyataan kongkret mengenai suatu sebab dan ada pula dengan bahasa samar, yang kurang jelas maksudnya yang hanya mengandung kemungkinan mengenainya. Bentuk redaksi asbabun nuzul sebagai berikut :

Pertama : Apabila perawi menerangkan dengan lafal "sebab" atau menggunakan fa ta'qbiyah (fa huruf athaf yag mempunyai arti "maka" atau "kemudian" yang dirangkaikan dengan kata "turunlah ayat", sesudah penyebutan peristiwa atau pertanyaan misalnya yang artinya :

“ terjadi peristiwa ini atau Nabi SAW ditanya tentang peristiwa ini, maka turunlah ayat ini"

Dengan demikian, bentuk ungkapkan diatas merupakan pernyataan yang jelas tentang sebab.

Kedua : Redaksi yang menerangkan sebab nuzul atau hanya sekedar menjelaskan kandungan hukum suatu ayat. Hal ini terjadi apabila perawi mengatakan (aku mengira ayat ini turun mengenai soal begini) atau (aku tidak mengira ayat ini turun kecuali mengenai hal yang begini (Al Qattan : 86). Dengan bentuk redaksi demikian ini, perawi tidak memastikan sebab nuzul. Kedua bentuk redaksi tersebut mungkin menunjukkan sebab nuzul dan mungkin pula menunjukkan yang lain contoh pertama, firman Allah SWT dalam surat Al Baqarah : 223

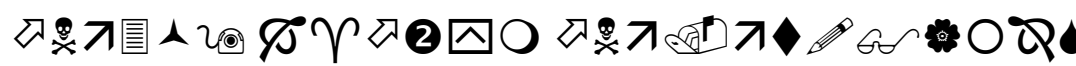

"Istri-isti kamu adalah ibarat tanah tempat kamu bercocok tanam...."
} 
Ayat tersebut turun terkait dengan anggapan orang Yahudi bahwa mendatangi istri dari belakang menyebabkan juling pada anak (As Suyuty : 89).

Contoh kedua, firman Allah dalam surat An Nisa : 65 yang berbunyi :

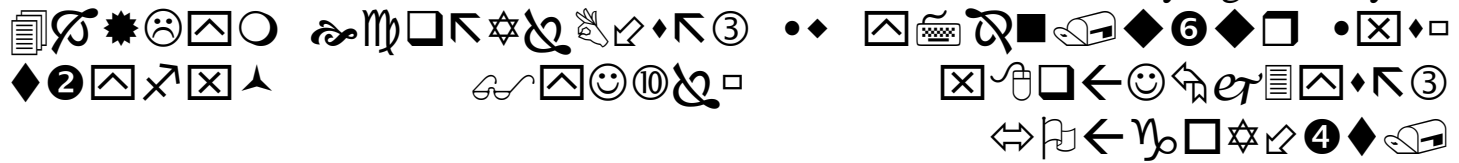

“ maka demi Tuhanmu, mereka apad hakekatnya tidak beriman hingga menjadikan kamu hakim terhadap perkara yang mereka perselisihkan....”

Ayat tersebut berkaitan dengan peristiwa pada Abdullah bin Zubair ketika ia mengajukan gugatan kepada seorang laki-laki dari orang Ansor yang pernah ikut perang badar bersama Nabi SAW. Keduanya melaporkan kepada Rasulullah tentang saluran air yang mengalir dari tempat yang tinggi ke kebun kurma mereka masing-masing. Orang Ansor membiarkan airnya mengalir, tetapi Zubair menolak. Maka Rasul menyuruh Zubair untuk mengairi kebunnya agar airnya bisa mengalir ke kebun tetangganya (Al Qurtuby : 234).

\section{Beberapa Riwayat Tentang Asbabun Nuzul}

Sikap seorang mufassir menanggapi banyaknya riwayat mengenai asbabun nuzul.

Dalam hal ini berlaku kaidah : yang artinya :

"bermacam-macam sebabnya, sedang ayat yang turun hanya satu atau bermacam-macam ayat yang turun, sedang sebabnya anya satu”

Adakalnya terdapat beberapa riwayat mengenai sebab turun suatu ayat dengan lafal yang jelas menerangkan sebab turun ayat, sikap para musafir dalam menanggapi riwayat-riwayat ini telah mempunyai ukuran mentarjih salah satu riwayat-riwayat itu. Sedang bila dijumpai dua riwayat yang kedua-duanya shahih, sedang tidak ada jalan untuk mentarjih diantara keduanya, maka langkah yang ditempuh adalah mengkompromikan dengan menetapkan, bahwa ayat ini turun setelah terjadi dua sebab itu. Berikut pernyataan terkait dengan beberapa riwayat asbabun nuzul.

Pertama, senantiasa berpegang terhadap riwayat yang shahih, contohnya : firman Allah SWT dalam surat Adh-duha. Diriwayatkan oleh imam Bukhari, Muslim, dan ahli hadist lainnya bahwa sebab turunnya surat 
Adh-Dhuha adalah terkait dengan sakit yang diderita oleh Nabi SAW. Hingga beliau dua atau tiga malam beliau tidak bangun malam. Kemudian datanglah seorang perempuan, Ummu Jamil isteri Abu Lahab, kepadanya dan berkata : “ Muhammad, kurasa setanmu sudah meninggalkanmu, selama dua tiga malam ini sudah tidak mendekatimu lagi. "maka Allah SWT menurunkan firman-Nya surat Adh-Duha (Al Qurtuby, Jilid 19:70).

Sementara Tabari dan Ibn Abi Syaibah meriwayatkan lain. Menurutnya sebab turunnya ayat tersebut adalah berkaitan dengan seekor anjing yang telah masuk ke rumah Nabi SAW. Lalu masuk ke kolong tempat tidur dan mati. Karenanya selama empat hari tidak turun wahyu kepadanya. Pembantu Rasulullah, Khaulah berinisiatif membenahi rumah dan menyapu tempat tidurnya dengan mengeluarkan bangkai anjing. Pada waktu itu pula Khaulah melihat janggut Nabi bergetar bahwa telah turun wahyu kepadnya. Allah telah menurunkan wahyu surat adh duha pada nabi SAW. Dalam hal ini kita berpegang pada riwayat yang shahih Bukhari dan Muslim bukan periwayatan dari Tabari, karena dalam periwayatannya terdapat orang yang tidak dikenal.

Kedua, mengkompromikan riwayat-riwayat yang sama kuat, misalnya firman Allah dalam surat An-Nur : 6-9 tentang li'an

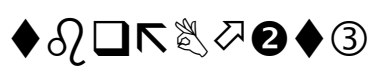

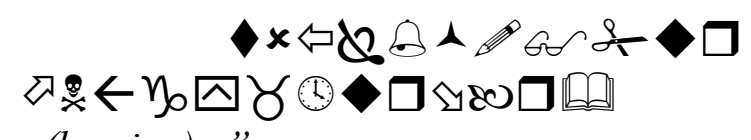

"Dan orang yang menuduh istrinya (berzina)..."

Bukhari, Muslim dan Ibn Majah meriwayatkan dari Ibn Abbas bahwa ayat tersebut turun mengenai Hilal bin Umayah yang menuduh istrinya telah berbuat serong dengan Syuraik bin Sahma'

Dalam riwayat yang lain, Bukhari, Muslim meriwayatkan dari Sahal bin Sa'ad bahwa Uwaimir menyuruh 'Asim bin Adi' untuk menanyakan tindakan apa yang selayaknya diambil oleh suami ketika mendapati istrinya bersama-sama laki-laki lain. Kedua riwayat ini dapat dipadukan, yaitu bahwa peristiwa Hilal terjadi lebih dahulu, dan kebetulan pula 'Uwaimir mengalami kejadian serupa, maka turunlah ayat yang berkenan dengan urusan kedua orang itu. 


\section{Banyaknya Nuzul dengan satu sebab}

Terkadang banyak ayat yang turun, sedang sebabnya hanya satu. Banyak ayat yang turun di dalam berbagai surat berkenaan dengan satu peristiwa (Az Zarqoni:122). Contohnya firman Allah dalam surat Ali Imron : 195 yang berbunyi :

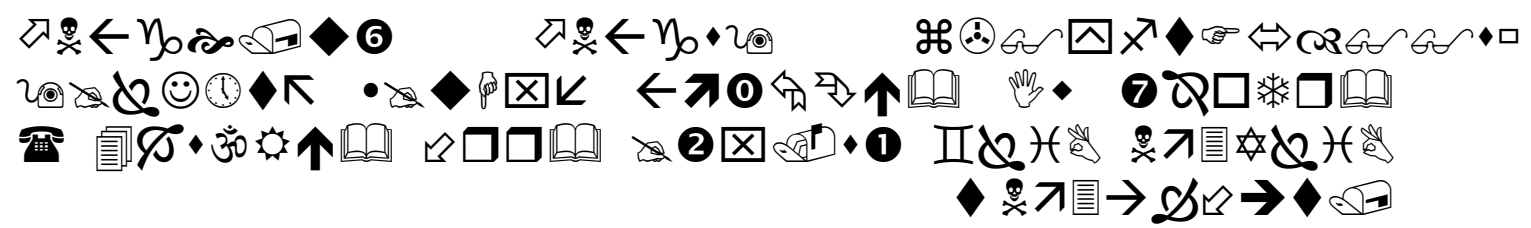

"Maka Tuhan mereka memperkenankan permohonannya : Sesungguhnya aku tidak menyia-nyiakan amal orang yang beramal diantara kamu, baik lakilaki maupun perempuan; (karena) sebagian kamu adalah turunan dari yang lainnya......"

Asbabun Nuzul ayat di atas berdasarkan riwayat dari Sa'id bin Mansur, Abdurrazaq, Tirmizi, Ibn Jarir, Ibn Munzir, Ibn Abi Hatim, Tabrani dan Hakim yang mengatakan shahih dari Ummu Salah. Dia mempertanyakan tentang tidak disebutkannya kaum perempuan dalam hijrah. Maka Allah SWT menurunkan ayat di atas.

Diriwayatkan pula oleh Ahmad, Nasa'i Ibn Jarir Ibn Munzir dan Tabaridan Ibn Mardawih dari Ummu Salamah yang bertanya kepada Nabi SAW tentang mengapa kaum perempuan tidak disebutkan dalam Al Qur'an seperti kaum laki-laki. Maka Allah menurunkan firman-Nya dalam surat Al Ahzab : 35 yang berbunyi :

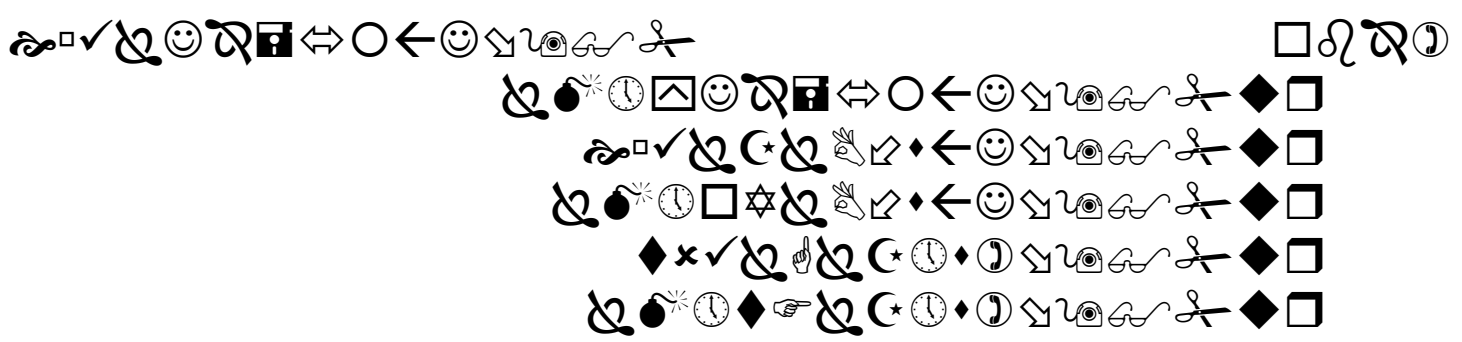

"Sesungguhnya laki-laki dan perempuan yang muslim, laki-laki dan perempuan yang mukmin, laki-laki dan perempuan yang tetap dalam ketaatannya....". 
Masih dari Ummu Salamah yang diriwayatkan oleh Hakim bahwa dia memprotes peran laki-laki yang bisa berperang sedangkan perempuan tidak. Disamping itu perempuan hanya memperoleh warisan setengah bagian. Maka Allah menurunkan Firman-Nya dalam surat An Nisa : 32

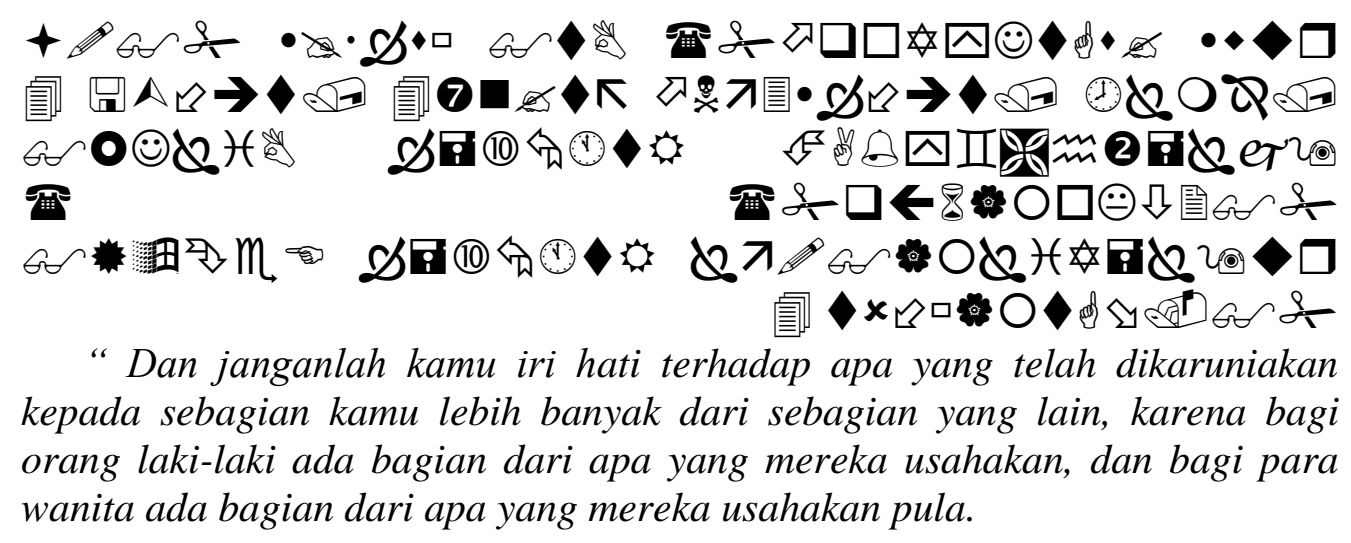

Dari uraian di atas tampak bahwa ketiga ayat tersebut turun karena satu sebab.

\section{Kesimpulan}

Dari uraian di atas dapat disimpulkan bahwa pengetahuan tentang asbabun nuzul merupakan langkah awal untuk mengetahui peristiwa yang melatarbelakangi pada saat turunnya Al Qur'an. Kemudian turunlah satu atau beberapa ayat yang menjelaskan hukum pada peristiwa tersebut, atau berupa pertanyaan yang dihadapkan kepada Rasulullah SAW, lalu turunlah satu ayat atau beberapa ayat, yang di dalamnya terdapat jawabannya.

\section{Daftar Pustaka}

Muhammad Abdul Al-Adhim Az-Zarqani, Manahil al-Irfan Fi Ulum Al-Qur'an Beirut: Dar AlFikr, 1988

Al Qurtuby, Ahmad Al-Anshaary, Al Jami' Li Al Ahkam Al Qur'an Tafsir Al Qurtuby. Kairo:Maktabah Taufiqiyah,tt

Ibn Rusd, Bidayah Al Mujtahid Wa Nihayah Al Muqtasid. Semarang Noor Asia,tt

Abdurrahman, A'isyah, Tafsir Bintusy Syathi'. Terjemahan Bandung, Mizan, 1996

Zaidan, Jurzi, Al arab Qabla Islam. Beirut: dar al Hayat, 1966

Al Qattan, Manna' Khalil, Mabahis Fi Ulum Al Qur'an. Kairo: Munsarat al "Isr Al Hadist 
203 - Asbabun $\mathcal{N u z u l ~ s e 6 a g a i ~ L a n g k a h ~ A w a l ~ M e n a f s i r k a n ~ A l ~ Q u r ' a n ~}$

As Syuyuty, Jalaluddin Abdurrahman, Al Itqan fi Ulum Al Qur'an. Beirut: Dar Ibn Katsir, Jilid II, 1996.

As Syayis, Muhammad ali, Tafsir Ayat Al-Ahkam, Beirut:Dar Kutub Ilmiah, Jilid I, 1988.

Bukhari, Imam, Shahih Bukhary. Beirut: Dar Al Fikr, 1996 